\title{
Ethanolic Extract of Ocimum sanctum Leaves Reduced Invasion and Matrix Metalloproteinase Activity of Head and Neck Cancer Cell Lines
}

\author{
Kusumawadee Utispan ${ }^{1,2 *}$, Nattisa Niyomtham ${ }^{2,3}$, Boon-ek Yingyongnarongkul $^{4}$, \\ Sittichai Koontongkaew ${ }^{1,2,3}$
}

\begin{abstract}
Background: Head and neck squamous cell carcinoma (HNSCC) has a yearly incidence of 600,000 cases worldwide with a low survival rate. Ocimum sanctum L. or Ocimum tenuiflorum L. (Holy basil; Tulsi in Hindi), is a traditional medicine herb that demonstrates numerous effects including anti-oxidant, anti-microbial, and anti-tumor effects. The aim of this study was to evaluate the anti-invasive effect of O. sanctum leaf extract on HNSCC cell lines. Methods: Ethanolic extract of O. sanctum leaf(EEOS) was prepared and the phenolic compounds were identified using high-performance liquid chromatography-electrospray ionization-time of flight-mass spectrometry. Genetically matched HNSCC cell lines derived from primary (HN30 and HN4) and metastatic sites (HN31 and HN12) from the same patient were used in this study. The EEOS cytotoxicity to the cell lines was determined using an MTT assay. The invasion and matrix metalloproteinase (MMP)-2 and -9 activity of EEOS-treated cells were tested using a modified Boyden chamber assay and zymography, respectively. Results: We found that EEOS significantly inhibited the invasion and MMP-2 and MMP-9 activity of HN4 and HN12 cells, but not HN30 and HN31 cells. Rosmarinic acid, caffeic acid, and apigenin were detected in EEOS. Moreover, rosmarinic acid was found as the major phenolic compound. Conclusion: EEOS exerted its anti-invasive effect on HNSCC cells by attenuating MMP activity. The active compounds identified in EEOS might be promising as an alternative therapeutic agent for HNSCC.
\end{abstract}

Keywords: Ethanolic extract of O. sanctum leaves- head and neck squamous cell carcinoma- invasion

Asian Pac J Cancer Prev, 21 (2), 363-370

\section{Introduction}

Head and neck squamous cell carcinoma (HNSCC) originates in the epithelial cells of the mucosal linings of the oral cavity, oropharynx, larynx, or hypopharynx (Argiris et al., 2008). HNSCC has an incidence of 600,000 cases per year worldwide, with a $40-50 \%$ mortality rate (Ferlay et al., 2015). Similar to other tumors, invasion and metastasis are the critical processes that indicate HNSCC aggressiveness (Leemans et al., 2018). Matrix metalloproteinase (MMPs) are the key enzymes involved in tumor invasion and metastasis. MMP-2 and MMP-9 destroy the basement membrane and degrade the extracellular matrix, promoting tumor invasion (Koontongkaew, 2013). Although modern medicine has contributed to treating cancers by surgery, chemotherapy, and radiotherapy, these modalities have not significantly changed the survival rate over the past three decades (Kozakiewicz and Grzybowska-Szatkowska, 2018).
Thus, more effective treatments for local and metastatic HNSCC are needed.

Ocimum sanctum Linn. or Ocimum tenuiflorum Linn., commonly known as Holy Basil in English or Tulsi in Indian language (Baliga et al., 2013), is a highly potent medicinal herb that is native throughout the eastern tropical countries including Thailand (Bast et al., 2014; Suanarunsawat et al., 2016). O. sanctum is primarily composed of phytochemicals (Pattanayak et al., 2010). The fresh leaves and stem contain several flavonoids and phenolic compounds. Phenolic compounds such as apigenin, rosmarinic acid, cirsilineol, cirsimaritin, isothymusin, and isothymonin have been detected in $O$. sanctum leaf extracts (Gupta et al., 2002). The phytochemicals in this plant varies depending on different growing, harvesting, extraction, and storage conditions (Bhattacharyya and Bishayee, 2013). The leaf extracts of $O$. sanctum have numerous medicinal effects such as anti-oxidant (Kelm et al., 2000; Manikandan et al., 2008),

${ }^{1}$ Oral Biology Research Unit, Faculty of Dentistry, ${ }^{2}$ Center of Excellence in Medicinal Herbs for Treatment of Oral Diseases, Thammasat University (Rangsit campus), Pathum Thani, ${ }^{3}$ Walailak University International College of Dentistry, Walailak University, ${ }^{4}$ Department of Chemistry and Center of Excellence for Innovation in Chemistry, Faculty of Science, Ramkhamhaeng University, Bangkok, Thailand.*For Correspondence: kusumawadee.utispan@gmail.com 
wound healing (Goel et al., 2010), anti-microbial (Eswar et al., 2016) and anti-tumorigenic effects (Bhattacharyya and Bishayee, 2013). The ethanol extract of $O$. sanctum leaf (EEOS) has demonstrated anti-tumorigenic effects on several cancer types including gastric cancer (Manikandan et al., 2007), pancreatic cancer (Shimizu et al., 2013), non-small cell lung cancer (Kwak et al., 2014), and lung cancers (Magesh et al., 2009; Kim et al., 2010). EEOS exhibited a variety of therapeutic effects on tumor cells. EEOS decreased the expression of proteins involved in the proliferation, invasion, and angiogenesis of carcinogen-induced rat gastric carcinoma (Manikandan et al., 2007). Moreover, EEOS inhibited cancer invasion and metastasis. EEOS reduced vascular endothelial growth factor production and MMP-9 activity in metastatic-induced NCI-H460 non-small cell lung cancer cells by inhibiting the phosphatidylinositol 3-kinase (PI3K)/Akt signaling pathway (Kwak et al., 2014). Similarly, when treated with EEOS, Lewis lung carcinoma cell MMP-9 activity was inhibited (Kim et al., 2010).

This evidence suggests that EEOS has a wide range of activity against tumor invasion. However, there is no data concerning the effect of EEOS on HNSCC. We hypothesized that EEOS would reduce HNSCC cell invasion. Therefore, this study evaluated the toxicity and anti-invasive effectof EEOS on primary and metastatic HNSCC cell lines. Moreover, the chemical constituents of the EEOS were identified.

\section{Materials and Methods}

\section{Chemicals}

Caffeic acid, rosmaric acid, and apigenin were purchased from Sigma-Aldrich (St. Louis, MO). Acetonitrile (HPLC grade), ethanol, methanol, and formic acid (all analytical grade) were purchased from Merck (Darmstadt, Germany).

\section{O. sanctum leaf collection}

The $O$. sanctum leaves were collected in the Phra Pradaeng district, Samut Prakan province, in central Thailand, during the rainy season. The collected leaves were authenticated for taxonomic identification by The Forest Botany Division, Forest Herbarium-BKF, Thailand.

\section{O. sanctum leaf extraction}

The $O$. sanctum leaves were dried at room temperature and pulverized using a grinder. The $O$. sanctum powder was soaked in $95 \%$ ethanol for two weeks at room temperature. The extract was filtered through a 0.45 nm filter paper and concentrated using a rotary vacuum evaporator (Rotovapor R-215, BUCHI Labortechnik AG, Switzerland). The viscous residue was dried in a vacuum oven at $40^{\circ} \mathrm{C}$. The ethanolic extract of $O$. sanctum (EEOS) was stored as a powder at $4^{\circ} \mathrm{C}$ until used.

\section{Cell culture}

Genetically-matched HNSCC cell lines derived from primary and metastatic sites from the same patient were provided by Professor Silvio Gutkind (Moores Cancer
Center, Department of Pharmacology, UCSD, CA, USA). The HN30 and HN31 cells were obtained from primary pharynx lesions and lymph node metastases (T3N0M0), respectively. The HN4 and HN12 cells were obtained from primary tongue lesions and lymph node metastases (T4N1M0), respectively (Cardinali et al., 1995). The cells were maintained in Dulbecco's Modified Eagle's Medium (DMEM) (Invitrogen, Carlsbad, CA) supplemented with $10 \%$ fetal bovine serum, $100 \mathrm{U} / \mathrm{ml}$ penicillin, $100 \mu \mathrm{g} / \mathrm{ml}$ streptomycin (Invitrogen), and an anti-fungal agent. The cells were cultured in a $37^{\circ} \mathrm{C}$ humidified $5 \% \mathrm{CO}_{2}$ atmosphere. The cells were passaged with $0.25 \%$ trypsin-EDTA when $90-100 \%$ confluent. Only cultures with at least $95 \%$ cell viability were used in the experiments.

\section{MTT assay}

Cells (2,000 cells/well/100 $\mu \mathrm{l})$ were seeded in 96-well plates and incubated in a $37^{\circ} \mathrm{C}$ humidified $5 \% \mathrm{CO}_{2}$ atmosphere. The cells were treated with $0.05,0.1,0.2,0.4$, or $0.8 \mathrm{mg} / \mathrm{ml}$ EEOS diluted in growth medium. Cells in growth medium served as control. After a $72 \mathrm{~h}$ incubation, the amount of viable cells in each treatment group were determined using thiazolylblue tetrazolium bromide (MTT, Sigma). The medium was removed, $150 \mu \mathrm{l}$ of fresh medium was added, followed by adding $50 \mu \mathrm{l} /$ well of 2 $\mathrm{mg} / \mathrm{ml}$ MTT solution. The plates were incubated for $4 \mathrm{~h}$ at $37^{\circ} \mathrm{C}$ in a $5 \% \mathrm{CO}_{2}$ incubator. The precipitated formazan crystals were solubilized in DMSO $(200 \mu \mathrm{l} /$ well $)$. The absorbance of the resulting solution was measured at 570 $\mathrm{nm}$ by a microplate reader (Tecan trading, Austria) and converted to percent viable cells compared with control. Cell viability ( $\%$ ) was determined as follows: cell viability $(\%)=($ mean Abs570treated cells - mean Abs570blank $) /$ (mean Abs570control cells - mean Abs570blank) $\times 100$. Three independent experiments were performed.

\section{Invasion assay}

To evaluate cell invasion, an in vitro assay for cell invasion through Matrigel was performed using a blind-well Boyden chemotaxis chamber (Neuro Probe, Gaithersburg, MD) as previously described (Albini et al., 1987). Briefly, the upper surface of $13 \mu \mathrm{m}$ pore polycarbonate filters (Fisher Scientific, Canada) was coated with Matrigel, a reconstituted basement membrane gel (Corning, Tewksbury, MA) and placed between the upper and lower well plates of a blind-well Boyden chemotaxis chamber. Growth medium was used as a source of chemoattractants in the lower chamber. HNSCC cells $\left(8 \times 10^{4}\right.$ cells) were resuspended in $0.4 \mathrm{mg} / \mathrm{ml} \mathrm{EEOS}$ diluted in DMEM containing $0.1 \%$ BSA and were seeded into the upper well of the chamber. Cells treated with DMEM containing $0.1 \%$ BSA served as control. After 5 $\mathrm{h}$ incubation in $37^{\circ} \mathrm{C}$ and $5 \% \mathrm{CO}_{2}$ atmosphere incubator, the non-migrating cells on the upper surface of the filter were wiped off with a cotton bud. The filters were fixed with $0.5 \%$ crystal violet in $25 \%$ methanol for $10 \mathrm{~min}$. The invaded cells on the lower surface of the filters were counted under a microscope at $400 \times$ magnification. Cell counting was performed by two investigators. Five randomly selected fields were counted per filter in each 
group, and the counts were averaged. Three independent experiments were performed.

\section{Conditioned medium preparation and zymography}

HNSCC cells $\left(2 \times 10^{6}\right.$ cells) were cultured in 6-well plates and incubated at $37^{\circ} \mathrm{C}$ for $24 \mathrm{~h}$. After incubation, the wells were washed with PBS and treated with $0.4 \mathrm{mg} /$ $\mathrm{ml}$ EEOS diluted in DMEM containing 0.1\% BSA for 48 h. Cells cultured in DMEM containing $0.1 \%$ BSA were used as control. Conditioned medium (CM) was collected and centrifuged at $1,000 \mathrm{~g}$ and $4^{\circ} \mathrm{C}$ for $10 \mathrm{~min}$. The $\mathrm{CM}$ was stored at $-80^{\circ} \mathrm{C}$ until used. Total protein in the $\mathrm{CM}$ was estimated using the PierceTM BCA protein assay kit (Thermo Fisher Scientific, Waltham, MA).

MMP-2 and MMP-9 activity in the CM were measured using gelatin zymography as previously described (Thomas et al., 2001). Briefly, gelatin (bloom 300, Sigma) was added to a $10 \%$ acrylamide separating gel at a final concentration of $0.2 \%$. Samples containing equal amounts of total protein were mixed with non-reducing sample buffer and added to the gel. Following electrophoresis, the gels were washed in $2.5 \%$ Triton $\mathrm{X}-100$ for $30 \mathrm{~min}$ at $37^{\circ} \mathrm{C}$. The gels were incubated at $37^{\circ} \mathrm{C}$ overnight in developing buffer. The gels were stained with $0.5 \%$ Coomassie blue G250 in a 30\% methanol and 10\% glacial acetic acid solution for $30 \mathrm{~min}$ and destained in the same solution without Coomassie blue. The gelatin-degrading enzymes were identified as clear bands against the blue background of the stained gel. Images of the stained gels were captured under illumination using a G:BOX gel documentation system (Syngene, Frederick, MD). The gelatinolytic bands were quantified using GeneTools software (Syngene, Frederick, MD). Three independent experiments were performed.

\section{HPLC-ESI-TOF-MS analysis of EEOS}

The $\mathrm{O}$. sanctum extract was chemically analyzed using high-performance liquid chromatography coupled with electrospray ionization-time of flight-mass spectrometry (HPLC-ESI-TOF-MS). EEOS (2 $\mathrm{mg} / \mathrm{ml})$ was filtered through a $0.45 \mu \mathrm{m}$ membrane filter and injected into an HPLC system (UltiMate ${ }^{\circledR} 3000$ system, Thermo Fisher Scientific, Sunnyvale, CA). Caffeic acid (0.5, 1.0, 1.5, 2.0, 2.5, 3.0, and $3.5 \mu \mathrm{g} / \mathrm{ml}$ ), rosmarinic acid (1.0, 5.0, $10.0,15.0,20.0,25.0$, and $30.0 \mu \mathrm{g} / \mathrm{ml})$, and apigenin $(0.1,0.5,1.0,1.5,2.0,2.5$, and $3.0 \mu \mathrm{g} / \mathrm{ml})$ standards were prepared. HPLC was performed using a reverse phase column (Symmetry C18 analysis column, $2.1 \mathrm{~mm}$ x 150 $\mathrm{mm}$, and $5 \mu \mathrm{m}$ particle size). A gradient mobile phase system consisting of $0.1 \%$ formic acid (Component A) and acetonitrile (Component B). Elution was performed at a $0.3 \mathrm{ml} / \mathrm{min}$ flow rate. The gradient elution program was: $5-15 \% \mathrm{~B}$ (0-26 min), 15-35\% B (26-28 min), and $35-95 \%$ B (28-50 min). The injection volume was $5 \mu 1$ and the column temperature was $40^{\circ} \mathrm{C}$. The components that were separated by the HPLC system were subjected to mass to charge ratio $(\mathrm{m} / \mathrm{z})$ analysis using an ESI-TOF-MS system. ESI-TOF-MS was performed using a time of flight mass spectrometer (micrOTOF-Q-II, Bruker Daltonics, Germany). The ESI system negative-ion mode was used to generate $\mathrm{m} / \mathrm{z}$ in a range $50-1,000$. The optimized mass spectrometric conditions were gas temperature $\left(200^{\circ} \mathrm{C}\right)$, drying gas flow rate $(81 / \mathrm{min})$, nebulizer gas pressure $(2$ bar), and the capillary potential was 3,000 V. Quantitative determination of the EEOS phenolic components was performed using a standard calibration curve. The data was analyzed using DataAnalysis 4.0 software (Bruker Daltonics, Germany).

\section{Statistical analysis}

The results are presented as means and standard error of the mean (SEM). Statistical analysis was performed using one-way ANOVA followed by the Tukey's multiple comparisons test with Prism GraphPad 7.0 (GraphPad Software, La Jolla, CA). The significance level was set at 0.05 .

\section{Results}

Cytotoxic assessment of EEOS on the HNSCC cell lines

The cytotoxic effect of EEOS on the HNSCC cell lines was evaluated using an MTT assay (Figure 1). EEOS (0.8 $\mathrm{mg} / \mathrm{ml}$ ) significantly decreased the HN30, HN31, HN4, and HN12 cell viability to approximately 40\%, 53\%, $52 \%$, and $40 \%$, respectively, of that of their controls $(\mathrm{P}<$ $0.05)$. Whereas, $0.05,0.1,0.2$, and $0.4 \mathrm{mg} / \mathrm{ml}$ EEOS were non-toxic to the cell lines. Therefore, the HNSCC cell lines were treated with $0.4 \mathrm{mg} / \mathrm{ml}$ EEOS and their invasion and MMP-2 and-9 activity were evaluated.

\section{EEOS decreased metastatic HNSCC invasion}

We found that HN30 and HN31 cell line invasion was not significantly inhibited by the non-toxic dose of EEOS $(0.4 \mathrm{mg} / \mathrm{ml})$ compared with control $(\mathrm{P}>0.05)$ (Figures $2 \mathrm{~A}$ and $\mathrm{B}$ ). In contrast, $0.4 \mathrm{mg} / \mathrm{ml}$ EEOS significantly inhibited the invasion of the HN4 and HN12 cell lines by approximately $30 \%$ compared with control $(\mathrm{P}<0.05)$ (Figures 2C and D).

\section{EEOS reduced the MMP-2 and -9 activity of HNSCC cell lines}

MMP-2 and MMP-9 activity was detected and

Table 1. Retention Time, Calculated and Measured Masses, Calculated Formula, Concentration and Putative Identification of the 3 Compounds in EEOS Analyzed by HPLC-ESI-TOF-MS

\begin{tabular}{lcccccc}
\hline Compounds & $\begin{array}{c}\text { Retention time } \\
(\mathrm{min})\end{array}$ & $\begin{array}{c}\text { Calculated } \\
\text { mass }[\mathrm{M}-\mathrm{H}]- \\
(\mathrm{m} / \mathrm{z})\end{array}$ & $\begin{array}{c}\text { Measured } \\
\text { mass }[\mathrm{M}-\mathrm{H}]- \\
(\mathrm{m} / \mathrm{z})\end{array}$ & $\begin{array}{c}\text { Calculated } \\
\text { formula } \\
{[\mathrm{M}-\mathrm{H}]-}\end{array}$ & $\begin{array}{c}\text { Concentration } \\
(\mu \mathrm{g} / \mathrm{ml})\end{array}$ & $\begin{array}{c}\text { Putative } \\
\text { identification }\end{array}$ \\
\hline 1 & 7.8 & 179.0353 & 179.0349 & $\mathrm{C}_{9} \mathrm{H}_{7} \mathrm{O}_{4}$ & 1.72 & Caffeic acid \\
2 & 24.8 & 359.0773 & 359.0772 & $\mathrm{C}_{18} \mathrm{H}_{15} \mathrm{O}_{8}$ & 15.71 & Rosmarinic acid \\
3 & 35.8 & 269.0461 & 269.0455 & $\mathrm{C}_{16} \mathrm{H}_{9} \mathrm{O}_{5}$ & 0.81 & Apigenin \\
\hline
\end{tabular}


A

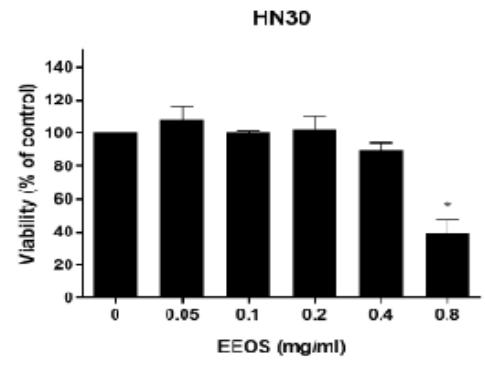

C

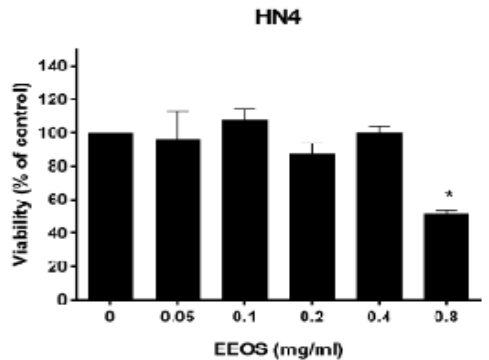

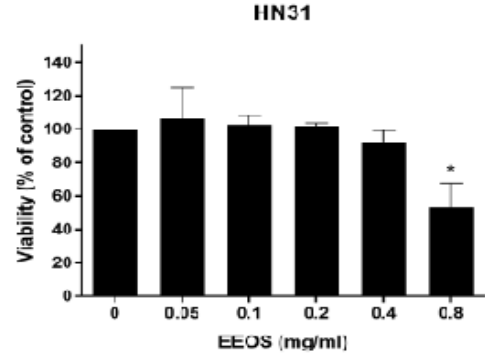

D

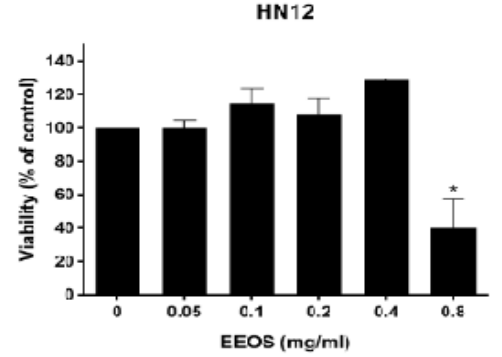

Figure 1. Cytotoxic Evaluation of EEOS on HNSCC Cells Measured by MTT Assay. EEOS in a range of concentrations were used to treat (A) HN30, (B) HN31, (C) HN4, and (D) HN12 cells for 72 h. Bars represent means \pm SEM (n=3). $*$ indicates $\mathrm{p}<0.05$ compared with control.

quantified as gelatinolytic bands and arbitrary number of intensity, respectively. We found that $0.4 \mathrm{mg} / \mathrm{ml}$ EEOS treatment did not alter the MMP-2 and MMP-9 activity of HN30 and HN31 cells (Figure 3A). However, the MMP-2 and MMP-9 activity of HN4 and HN12 cells were downregulated when treated with EEOS (Figure 3B). Quantitative analysis of the MMP activity revealed that the MMP-2 and MMP-9 activity in EEOS-treated HN30 and HN31 cells and control cells were not significantly different $(\mathrm{P}>0.05)$ (Figures $3 \mathrm{C}$ and $\mathrm{D})$. Differently,
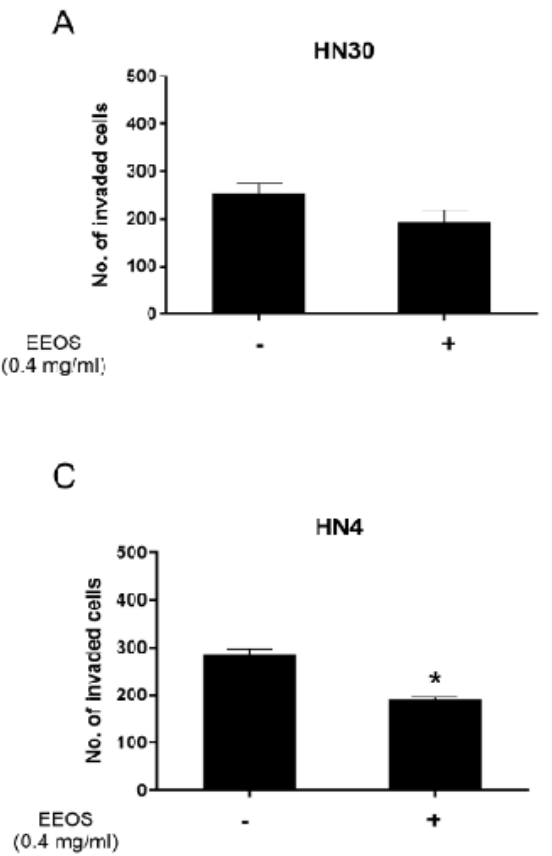

$0.4 \mathrm{mg} / \mathrm{ml}$ EEOS significantly reduced HN4 and HN12 cell MMP-2 activity to approximately $65 \%$ and $71 \%$, respectively, of that of the control cells $(\mathrm{P}<0.05)$. In addition, $0.4 \mathrm{mg} / \mathrm{ml}$ EEOS significantly reduced the MMP-9 activity of the HN4 and HN12 cells to approximately $44 \%$ and $85 \%$, respectively, of that of the control cells $(\mathrm{P}<0.05)$ (Figures $3 \mathrm{C}$ and $\mathrm{D})$.

\section{HPLC analysis of EEOS}

Baseline calibration of HPLC system was performed

B

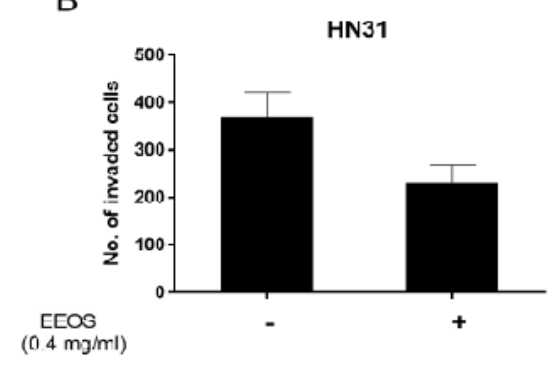

D

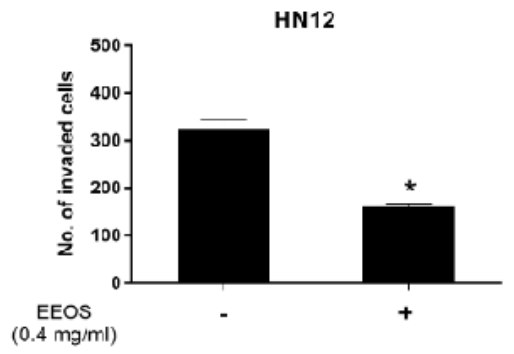

Figure 2. EEOS Decreased HNSCC Cell Invasion. A non-cytotoxic dose of EEOS was used to treat (A) HN30, (B) $\mathrm{HN} 31$, (C) HN4, and (D) HN12 cells and evaluated cell invasion. Bars represent means $\pm \mathrm{SEM}(\mathrm{n}=3$ ). * indicates $\mathrm{p}<0.05$ compared with control. 


\section{A}

$2 \mathrm{kDa}$

$72 \mathrm{kDa}$

$62 \mathrm{kDa}$

EEOS

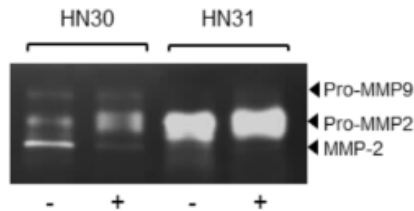

C

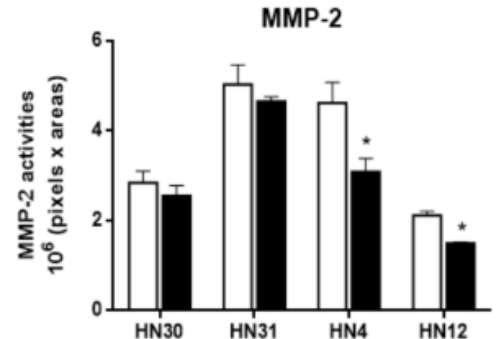

B

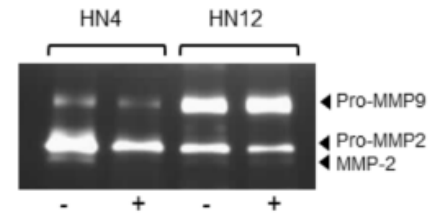

D

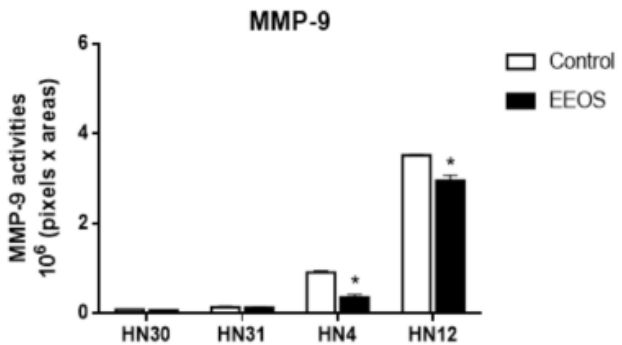

Figure 3. EEOS Reduced MMP Aactivity. The HNSCC cell lines were treated with $0.4 \mathrm{mg} / \mathrm{ml} \mathrm{EEOS} \mathrm{for} 48 \mathrm{~h}$ and the MMP activity in the conditioned media of (A) HN30 and HN31 cells, and (B) HN4 and HN12 cells were detected using zymography. GeneTools software was used to quantify the gelatinolytic bands of (C) MMP-2 and (D) MMP-9 activity. Bars represent means \pm SEM $(n=3)$. * indicates $\mathrm{p}<0.05$ compared with the control.

using the sample solvent (Figure 4A). The EEOS chromatograms demonstrated peaks 1,2 , and 3 with retention times that corresponded to those of the caffeic acid, rosmarinic acid, and apigenin standards, respectively (Figures 4B and C).

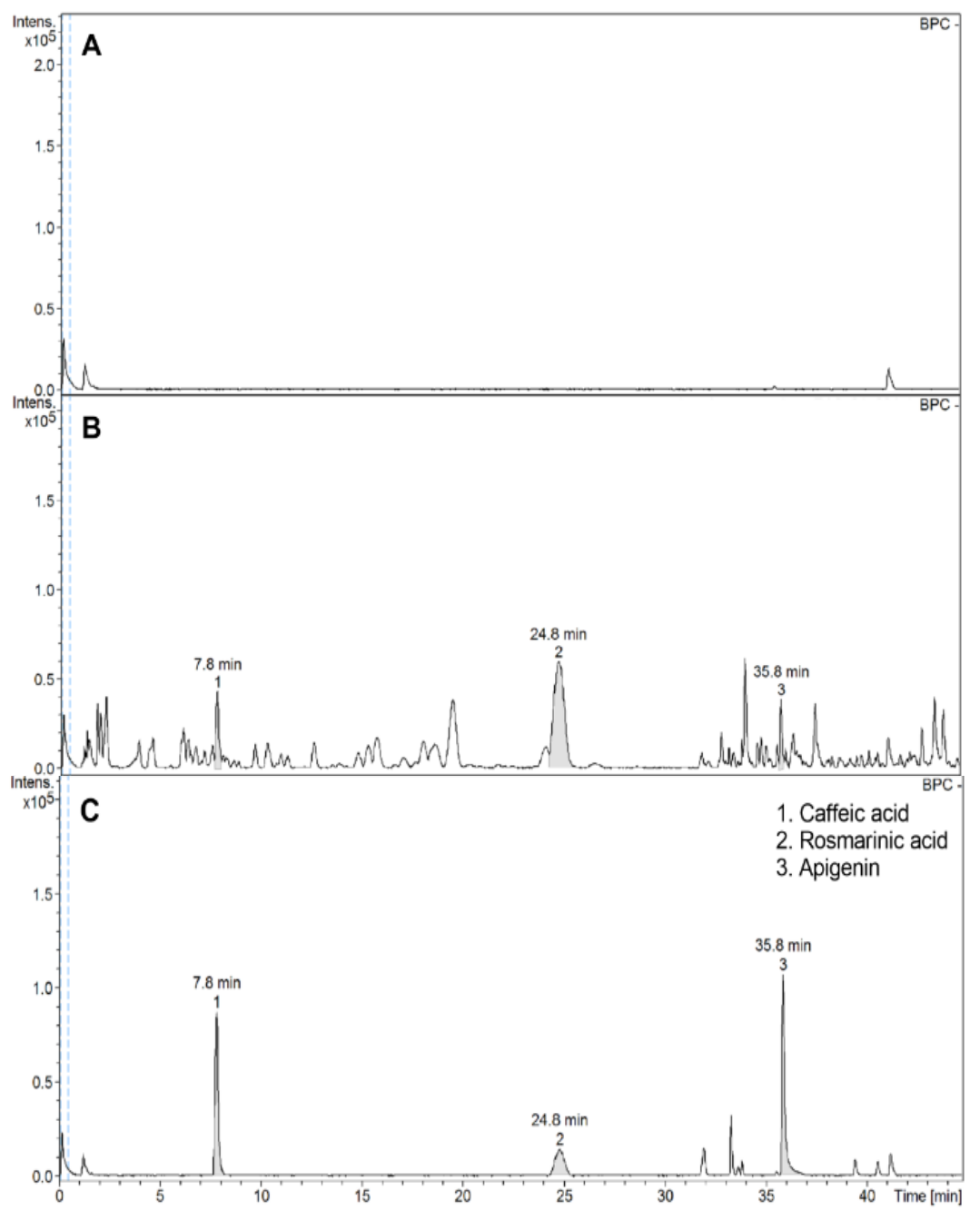

Figure 4. HPLC Analysis of EEOS. Chromatogram of (A) base line calibration, (B) EEOS and (C) standard phenolic compounds are shown with retention time ( $\mathrm{min})$. 
Compound 1<smiles>O=C(O)/C=C/c1ccc(O)c(O)c1</smiles>

Caffeic acid
Compound 2<smiles>O=C(/C=C/c1ccc(O)c(O)c1)OC(Cc1ccc(O)c(O)c1)C(=O)O</smiles>

Rosmarinic acid
Compound 3

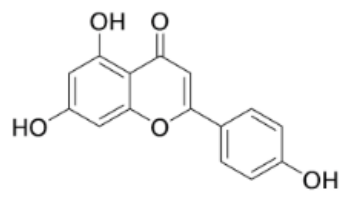

Figure 5. Putative Structure of the Compounds in EEOS. The chemical structure of compounds 1, 2, and 3 in EEOS are identified from the calculated formula in Table 1.

\section{Structural identification of the compounds in EEOS}

HPLC-ESI-TOF-MS parameters were optimized and used to profile the EEOS. The selected 3 compounds in EEOS were putatively identified by comparison to the database and quantified under the curve of standard compounds (Table 1). Quantification of the EEOS caffeic acid, rosmarinic acid, and apigenin indicated that rosmarinic acid was the major phenolic component. Moreover, structures of the putative compounds were drawn by comparison to the known structure of standard compounds. The results revealed that compounds 1, 2, and 3 were caffeic acid, rosmarinic acid, and apigenin, respectively (Figure 5).

\section{Discussion}

The present study investigated the effects of crude O. sanctum leaf extract on HNSCC invasiveness. EEOS cytotoxicity on the HNSCC cell lines was evaluated to determine the concentration to be used in subsequent experiments. A previous study reported that $0.2 \mathrm{mg} / \mathrm{ml}$ EEOS demonstrated a significant cytotoxic effect on a lung cancer cell line (A549) and mouse Lewis lung carcinoma cells (Magesh et al., 2009). However, $0.2 \mathrm{mg} / \mathrm{ml}$ EEOS was non-toxic to NCI-H460 non-small cell lung cancer cells (Kwak et al., 2014). Our findings indicated that 0.05 , $0.1,0.2$, and $0.4 \mathrm{mg} / \mathrm{ml}$ EEOS did not reduce HNSCC cell viability whereas, $0.8 \mathrm{mg} / \mathrm{ml}$ EEOS was toxic to the cell lines evaluated. Thus, the cytotoxic effect of EEOS may be cell type-dependent.

MMP-2 and MMP-9 activity is important in initiating tumor invasion (Koontongkaew, 2013). Several studies have reported the expression and role of MMP-2 and MMP-9 in HNSCC aggressiveness (de Vicente et al., 2005; Kato et al., 2005; Patel et al., 2007; Koontongkaew et al., 2012). We evaluated the effect of EEOS on HNSCC invasion and MMP activity. We found that EEOS decreased HN4 and HN12 cell invasion by attenuating MMP-2 and MMP-9 activity. In contrast, there was no significant change in $\mathrm{HN} 30$ and $\mathrm{HN} 31$ cell invasion or MMP activity after EEOS treatment. Increased MMP-2 and MMP-9 expression in human oral cancer tissues was significantly associated with T-stage and lymph node metastasis (de Vicente et al., 2005). Because HN4 and HN12 cells are derived from a stage IV tumor, EEOS may regulate their invasiveness by targeting their MMP-2 and MMP-9 activity. These results imply that EEOS may have a potent role in inhibiting the invasiveness of a stage IV tumor. However, further study is needed to confirm this hypothesis. A study demonstrated that EEOS reduced the metastatic activity of Lewis lung carcinoma cellinjected mice (Kim et al., 2010). They found that EEOS inhibited cancer invasion and MMP-9 activity, but not that of MMP-2. Another group confirmed that EEOS reduced MMP-9 and urokinase plasminogen activator activity in non-small cell lung cancer cells (NCI-H460) by inhibiting the PI3K/Akt signalling pathway (Kwak et al., 2014). MMP-9 production in HNSCC cell is induced through various signalling pathways, including epidermal growth factor receptor (EGFR), mitogen-activated kinase (MAPK), and PI3K/Akt (P et al., 2004; Koontongkaew et al., 2012). This suggests that EEOS may regulate MMP-2 and MMP-9 activity by targeting EGFR, MAPK, or PI3K/Akt pathways, leading to decreased HN4 and HN12 cell invasion.

The chemical composition of EEOS has been reported (Venuprasad et al., 2017). They found that EEOS was composed of several phenolic compounds and flavonoids, including rosmarinic acid and apigenin. Our results confirmed that the EEOS used in the present study contained rosmarinic acid, apigenin, and caffeic acid. Moreover, rosmarinic acid was the major phenolic component in our EEOS. Rosmarinic acid inhibited colon cancer invasion (Xu et al., 2010) and colorectal cancer metastasis (Han et al., 2018) by inhibiting MMP-2 and MMP-9 activity. These findings imply that the rosmarinic acid in EEOS may be a key factor in suppressing HNSCC cell invasion and MMP activity. Future studies should investigate the mechanism of rosmarinic acid and the other EEOS-derived components in suppressing HNSCC aggressiveness.

Taken together, the present study demonstrated the cytotoxic and anti-tumorigenic effects of EEOS on HNSCC invasion and MMP-2 and MMP-9 activity. Interestingly, EEOS selectively regulated the invasion and MMP activity of HN4 and HN12 cells that were derived from stage IV tumors. We showed that the phenolic compounds rosmarinic acid, caffeic acid, and apigenin were present in EEOS. Moreover, rosmarinic acid was found as a major phenolic component. These results suggest that EEOS may be used as an alternative therapeutic agent in clinical research. However, the anti-tumorigenic mechanisms of the active compounds in EEOS require further investigation. 


\section{Acknowledgements}

The authors thank Professor Silvio Gutkind (Moores Cancer Center, Department of Pharmacology, UCSD, CA, USA) for the HNSCC cell lines used in our study. We thank Miss Hataichanok Yindeesompong, Miss Parncheewee Boonyawattananun, and Miss Nudda Khamrapich for technical assistance. We thank Dr. Amornmart Jaratrungtawee for HPLC-ESI-TOF-MS technical advice. The English editing of this manuscript was kindly performed by Dr. Kevin Tompkins, Office of Research Affairs, Faculty of Dentistry, Chulalongkorn University.

\section{Funding Statement}

This work was supported by Faculty of Dentistry, Thammasat University (2559) and Center of Excellence for Innovation in Chemistry (2016).

\section{References}

Albini A, Iwamoto Y, Kleinman HK, et al (1987). A rapid in vitro assay for quantitating the invasive potential of tumor cells. Cancer Res, 47, 3239-45.

Argiris A, Karamouzis MV, Raben D, et al (2008). Head and neck cancer. Lancet, 371, 1695-709.

Baliga MS, Jimmy R, Thilakchand KR, et al (2013). Ocimum sanctum L (Holy Basil or Tulsi) and its phytochemicals in the prevention and treatment of cancer. Nutr Cancer, 65, 26-35.

Bast F, Rani P, Meena D (2014). Chloroplast DNA phylogeography of holy basil (Ocimum tenuiflorum) in Indian subcontinent. Sci World J, 2014, 847482.

Bhattacharyya P, Bishayee A (2013). Ocimum sanctum Linn. (Tulsi): an ethnomedicinal plant for the prevention and treatment of cancer. Anticancer Drugs, 24, 659-66.

Cardinali M, Pietraszkiewicz H, Ensley JF, et al (1995). Tyrosine phosphorylation as a marker for aberrantly regulated growth-promoting pathways in cell lines derived from head and neck malignancies. Int J Cancer, 61, 98-103.

de Vicente JC, Fresno MF, Villalain L, et al (2005). Expression and clinical significance of matrix metalloproteinase- 2 and matrix metalloproteinase-9 in oral squamous cell carcinoma. Oral Oncol, 41, 283-93.

Eswar P, Devaraj CG, Agarwal P (2016). Anti-microbial activity of Tulsi \{Ocimum Sanctum (Linn.)\} Extract on a periodontal pathogen in human dental plaque: An invitro study. J Clin Diagn Res, 10, ZC53-6.

Ferlay J, Soerjomataram I, Dikshit R, et al (2015). Cancer incidence and mortality worldwide: sources, methods and major patterns in GLOBOCAN 2012. Int $J$ Cancer, 136, $359-86$.

Goel A, Kumar S, Singh DK, et al (2010). Wound healing potential of Ocimum sanctum Linn. with induction of tumor necrosis factor-alpha. Indian J Exp Biol, 48, 402-6.

Gupta SK, Prakash J, Srivastava S (2002). Validation of traditional claim of Tulsi, Ocimum sanctum Linn. as a medicinal plant. Indian J Exp Biol, 40, 765-73.

Han YH, Kee JY, Hong SH (2018). Rosmarinic acid activates AMPK to inhibit metastasis of colorectal cancer. Front Pharmacol, 9, 68.

Kato K, Hara A, Kuno T, et al (2005). Matrix metalloproteinases 2 and 9 in oral squamous cell carcinomas: manifestation and localization of their activity. $J$ Cancer Res Clin Oncol, 131, 340-6.

Kelm MA, Nair MG, Strasburg GM, et al (2000). Antioxidant and cyclooxygenase inhibitory phenolic compounds from Ocimum sanctum Linn. Phytomedicine, 7, 7-13.

Kim SC, Magesh V, Jeong SJ, et al (2010). Ethanol extract of Ocimum sanctum exerts anti-metastatic activity through inactivation of matrix metalloproteinase- 9 and enhancement of anti-oxidant enzymes. Food Chem Toxicol, 48, 1478-82.

Koontongkaew S (2013). The tumor microenvironment contribution to development, growth, invasion and metastasis of head and neck squamous cell carcinomas. J Cancer, $\mathbf{4}$, 66-83.

Koontongkaew S, Amornphimoltham P, Monthanpisut P, et al (2012). Fibroblasts and extracellular matrix differently modulate MMP activation by primary and metastatic head and neck cancer cells. Med Oncol, 29, 690-703.

Kozakiewicz P, Grzybowska-Szatkowska L (2018). Application of molecular targeted therapies in the treatment of head and neck squamous cell carcinoma. Oncol Lett, 15, 7497-505.

Kwak TK, Sohn EJ, Kim S, et al (2014). Inhibitory effect of ethanol extract of Ocimum sanctum on osteopontin mediated metastasis of NCI-H460 non-small cell lung cancer cells. BMC Complement Altern Med, 14, 419.

Leemans CR, Snijders PJF, Brakenhoff RH (2018). The molecular landscape of head and neck cancer. Nat Rev Cancer, 18, 269-82.

Magesh V, Lee JC, Ahn KS, et al (2009). Ocimum sanctum induces apoptosis in A549 lung cancer cells and suppresses the in vivo growth of Lewis lung carcinoma cells. Phytother Res, 23, 1385-91.

Manikandan P, Vidjaya Letchoumy P, Prathiba D, et al (2007). Proliferation, angiogenesis and apoptosis-associated proteins are molecular targets for chemoprevention of MNNG-induced gastric carcinogenesis by ethanolic Ocimum sanctum leaf extract. Singapore Med J, 48, 645-51.

Manikandan P, Vidjaya Letchoumy P, Prathiba D, et al (2008). Combinatorial chemopreventive effect of Azadirachta indica and Ocimum sanctum on oxidant-antioxidant status, cell proliferation, apoptosis and angiogenesis in a rat forestomach carcinogenesis model. Singapore Med J, 49, 814-22.

P Oc, Wongkajornsilp A, Rhys-Evans PH, et al (2004). Signaling pathways required for matrix metalloproteinase-9 induction by betacellulin in head-and-neck squamous carcinoma cells. Int $J$ Cancer, 111, 174-83.

Patel BP, Shah SV, Shukla SN, et al (2007). Clinical significance of MMP-2 and MMP-9 in patients with oral cancer. Head Neck, 29, 564-72.

Pattanayak P, Behera P, Das D, et al (2010). Ocimum sanctum Linn. A reservoir plant for therapeutic applications: An overview. Pharmacogn Rev, 4, 95-105.

Shimizu T, Torres MP, Chakraborty S, et al (2013). Holy Basil leaf extract decreases tumorigenicity and metastasis of aggressive human pancreatic cancer cells in vitro and in vivo: potential role in therapy. Cancer Lett, 336, 270-80.

Suanarunsawat T, Anantasomboon G, Piewbang C (2016). Anti-diabetic and anti-oxidative activity of fixed oil extracted from Ocimum sanctum L. leaves in diabetic rats. Exp Ther Med, 11, 832-40.

Thomas GJ, Lewis MP, Hart IR, et al (2001). AlphaVbeta6 integrin promotes invasion of squamous carcinoma cells through up-regulation of matrix metalloproteinase-9. Int $J$ Cancer, 92, 641-50.

Venuprasad MP, Kandikattu HK, Razack S, et al (2017). Chemical composition of Ocimum sanctum by LC-ESI-MS/MS analysis and its protective effects against smoke induced lung and neuronal tissue damage in rats. Biomed Pharmacother, 91, 1-12.

Xu Y, Xu G, Liu L, et al (2010). Anti-invasion effect of rosmarinic acid via the extracellular signal-regulated kinase 
Kusumawadee Utispan et al

and oxidation-reduction pathway in Ls174-T cells. J Cell Biochem, 111, 370-9.

\section{@ $\mathbb{0} \otimes$}

This work is licensed under a Creative Commons AttributionNon Commercial 4.0 International License. 